Indonesian Journal of Physics and Nuclear Applications

Volume 2, Number 1, February 2017, p. 9-19

ISSN 2549-046X, (C) FSM UKSW Publication

\title{
A Study of The Assessment for Boron Neutron Capture Therapy Agent
}

\author{
Isman Mulyadi Triatmoko a, and Sutjipto ${ }^{a}$ \\ ${ }^{\mathrm{a}}$ Centre of Science and Accelerator Technology-BATAN Jl. Babarsari, \\ Yogyakarta,55281 Indonesia
}

\begin{abstract}
A study of the assessment criteria covers the synthesis and characterization of agent and test their biological effectiveness as boron neutron capture therapy (BNCT) agents in cancer treatment. The cellular uptake of this agent into the glioblastoma cells was assessed by boron analysis (ICP-MS) and by fluorescence imaging (confocal microscopy). The agent enters the glioblastoma cells exhibiting a similar profile, i.e., preferential accumulation in the cytoskeleton and membranes and a low cytotoxic activity $\left(\mathrm{IC}_{50}\right.$ values higher than $\left.200 \mu \mathrm{M}\right)$. The cytotoxic activity and cellular morphological alterations after neutron irradiation in the Research Reactor $\left(>10^{7}\right.$ neutrons $\left.\mathrm{cm}^{-2} \mathrm{~s}^{-1}\right)$ were assessed by the MTT assay and by electron microscopy (TEM). Post neutron irradiation revealed that BNCT has a higher cytotoxic effect on the glioblastoma cells. Results provide a strong rationale for considering one of these compounds as a lead candidate for a new BNCT agent.
\end{abstract}

Keywords : BNCT, ICP-MS, MTT assay, TEM, and $\mathrm{IC}_{50}$

\section{INTRODUCTION}

Malignant gliomas are the most common type of primary malignant brain tumor and the most frequently found brain tumor diagnosed in up to $49 \%$ of cases. According to the World Health Organization (WHO) glioblastoma or grade IV glioma is the most common form of gliomas and represents one of the most aggressive and treatment resistant types of human cancer were reviewed by A. Omuro et al and M. M. Mrugala. Glioblastoma remains an incurable disease despite technological and therapeutic improvements in surgery, radiotherapy and chemotherapy or combined therapeutic modalities. The outlook has improved only modestly, and the survival rate of patients stays less than a few percent were reviewed by C. Caruso et al, and C. P. Tanase et al. The therapeutic challenge is to develop strategies that can selectively target malignant cells, with little or no effect on normal cells and tissues adjacent to the tumor. One such approach is the so-called "binary therapy" in which two non-toxic components can be combined in order to produce a cytotoxic effect. The advantage is that each component can be modulated and manipulated independently to maximize the therapeutic efficacy. A potentially useful binary system is the boron neutron capture therapy (BNCT). As a binary treatment modality, BNCT combines a radiosensitizer, ${ }^{10} \mathrm{~B}(19.8 \%$ natural abundance) with thermal neutrons (n), an indirectly ionizing radiation. The subsequent $(\mathrm{n}, \alpha)$ reaction yields $1.47 \mathrm{MeV} \alpha$ particles and $0.84 \mathrm{MeV}{ }^{7} \mathrm{Li}$ ions, both having high linear energy transfer (LET) causing radiotoxic effects in the range of a cell diameter $(c a .10 \mu \mathrm{m})$. The efficient energy transfer produces selective damage in the cells containing ${ }^{10} \mathrm{~B}$ so that boron content and distribution in tumor are pivotal to the therapeutic efficacy of this treatment 
modality were reviewed by R. F. Barth et al, R. F. Barth and T. Yamamoto et al.

Boron atoms have to be targeted to tumor cells using a suitable boron carrier in order to maximize tumor cell damage and minimize the total radiation dose to the patient. The boron drugs sodium borocaptate (BSH) and boronophenylalanine (BPA) have been extensively assessment and are currently approved to treat glioma, melanoma, head and neck tumors and hepatocarcinoma were reviewed by M. A. Pisarev et al, S. Altieri et $a l$ and T. Kageji et al. These compounds are however far from ideal, exhibiting insufficient selectivity and efficiency, besides other limitations such as a reduced capability to cross the blood-brain barrier (BBB) and a poor water solubility (BPA) were reviewed by R. F. Barth et al, D. R. Lu, S. C. Mehta et al and A. H. Soloway et al. The subcellular distribution of these compounds in a glioma cell model showed that most of the boron was localized in the cytoplasm of the cells, but only minimal concentrations of boron existed in the nuclei were reviewed by T. Nguyen et al. A major challenge in the development of boron delivery agents is to deliver a sufficient amount of boron into the tumor cells to maximize the doses of radiation to the tumor with minimal normal tissue toxicity were reviewed by R. Gahbauer et al .

The use of boron clusters such as a dodecarborane instead of single boron atoms allows increasing the loading ability. Moreover, dodecarborane contains 10 boron atoms and possesses a rather low cytotoxicity and is compatible and extremely stable in biological medium were reviewed by I. B. Sivaev et al and C. Viñas i Teixidor et al. To increase the selectivity and efficacy of dodecarboranes towards cancer cells a large variety of derivatives have been designed and evaluated, taking into account specific features of cancer cells, such as enhanced metabolism and over-expression of target receptors were reviewed by C. H. Hsieh et al, A. Crivello et al, T. Betzel et al, J. Bonjoch et al and W. Yang et al. DNA binding agents and tumor seeking molecules like porphyrins and porphyrinic macrocyclic compounds, such as phthalocyanines, are also alternatives for selective delivery of the boron moiety into tumor cells were reviewed by R. P. Evstigneeva et al, M. W. Easson et al, E. L. Crossley et al, J. Yoo et al and N. P. Barry et al. However, until now there has been no new boron compound that has reached the stage for phase I clinical trials. Both BSH and BPA still remain today as the only two drugs in clinical trials for BNCT were reviewed by R. L. Moss et al.

Research on BNCT involves the design, synthesis and evaluation of more selective tumor targeting agents. The close proximity of the boron agent to DNA of tumor cells is also highly desirable. In addition, these compounds have attracted considerable attention from the scientific community due to their wide range of biological activities were reviewed by $P$. Belmont et al, G. Cholewiński et al and M. Koba et al. These results may offer new insights for consideration in malignant glioma treatment strategies.

\section{MATERIAL AND EQUIPMENT}

Most of the reagents used highly dependent on the compounds synthesized. All reagents were used without further purification. The internal standard was TMS. Nitrogen was used as a nebuliser gas and argon as a collision gas. Equipments used NMR and Thin Layer Chromatography. NMR spectra were recorded 
on Bruker Avance $300\left(300.13 \mathrm{MHz}\right.$ for ${ }^{1} \mathrm{H}$ and $75.47 \mathrm{MHz}$ for ${ }^{13} \mathrm{C}$ ) and Bruker Avance $500\left(500.13 \mathrm{MHz}\right.$ for ${ }^{1} \mathrm{H}$ and $125.76 \mathrm{MHz}$ for ${ }^{13} \mathrm{C}$ ) spectrometers, using $\mathrm{CDCl}_{3}$ as a solvent. Preparative thin layer chromatography was carried out with Riedel silica gel 60 DGF254 and column chromatography using Acros silica gel 60, 35-70 $\mu \mathrm{m}$.

\section{Synthesis}

Most of the reagents used highly dependent on the compounds synthesized. As an example of the synthesized compounds can be seen in Figure 1.

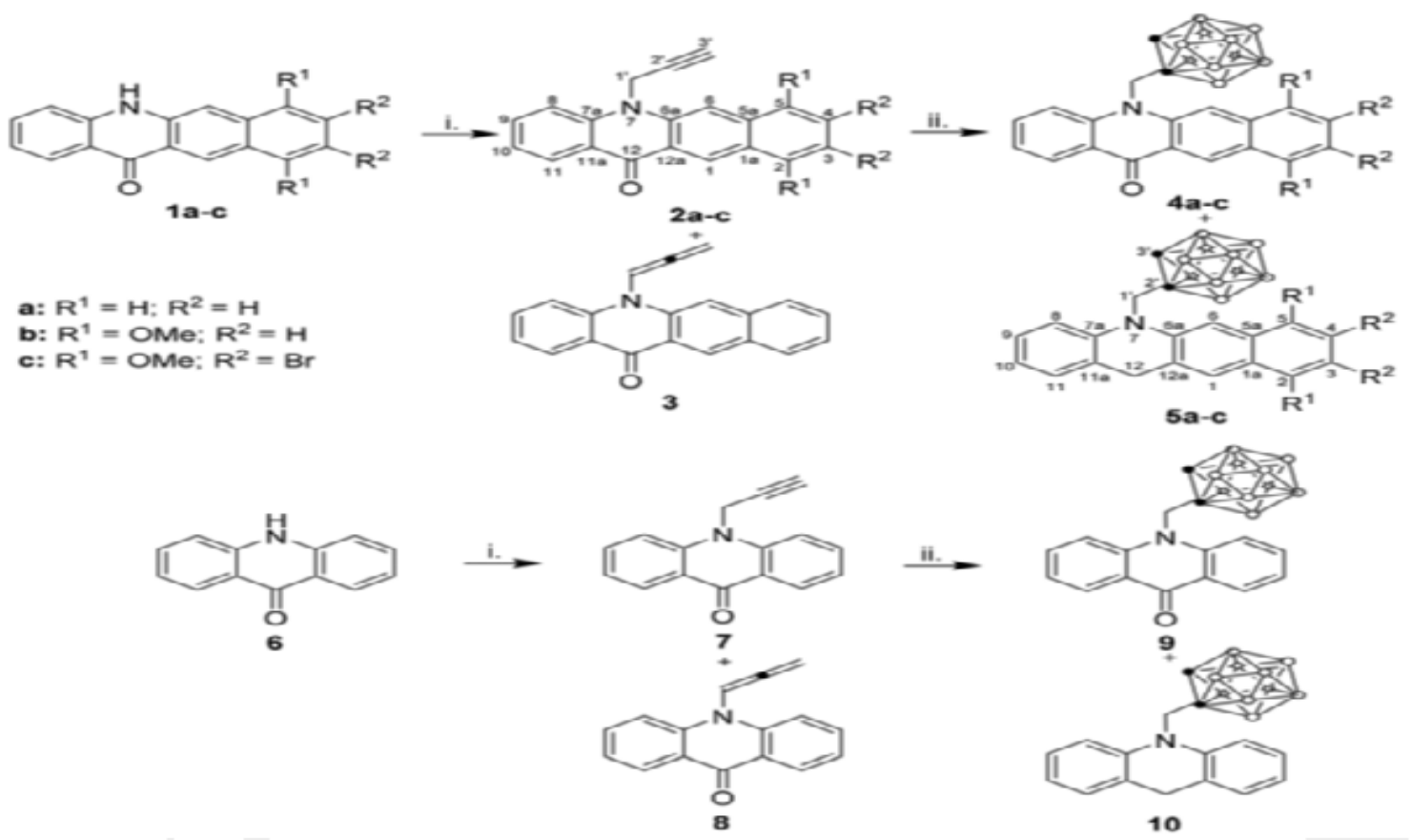

R. S. G. R. Seixas et al and J. A. S. Cavaleiro, A New Synthesis of Benzo[b]acridones, Synlett, 2008, 3193-3197.

Figure. 1 Synthetic pathway for the preparation of 7 -carboranylmethylbenzo[b]acridin-12(7H)-ones 4a-c and 10-carboranylmethylacridin-9(10H)-one (9). Reagents and conditions: (i) $\mathrm{BrH}_{2} \mathrm{CCuCH}, \mathrm{NaH}, \mathrm{THF}$ (dry), $40^{\circ} \mathrm{C}$, N2; (ii) $\mathrm{B}_{10} \mathrm{H}_{14}, \mathrm{CH}_{3} \mathrm{CN}$, toluene, $80^{\circ} \mathrm{C}, \mathrm{N} 2 . \bullet=$ $\mathrm{C}$ or $\mathrm{C}-\mathrm{H} ; \mathrm{O}=\mathrm{B}-\mathrm{H}$.

\section{Characterization}

Characterization a new BNCT agent using NMR equipment and Thin Layer Chromatography.

\section{Cell studies}

Cell culture and cellular viability. As an example human glioblastoma multiforme cell lines were cultured in DMEM with GlutaMax I (Gibco) containing 10\% fetal bovine serum and $1 \%$ antibiotics under a humidified atmosphere $(95 \%$ air $/ 5 \% \mathrm{CO} 2)$ at $37^{\circ} \mathrm{C}$. The cytotoxic activity of the boron compounds was determined using the MTT assay $\{$ MTT $=[3-$ (4,5-dimethylthiazol-2-yl)-2,5-

diphenyltetrazolium bromide]\} was described E. Vega-Avila et al.

The cellular viability was evaluated by comparing the absorbance of the resulting solutions at $570 \mathrm{~nm}$ for the treated cells with the absorbance for non-treated cells in a multi-well plate spectrophotometer. The cytotoxic activity of the compounds was quantified by calculating 
the drug concentration inhibiting tumor cell growth by $50 \%\left(\mathrm{IC}_{50}\right)$, based on non-linear regression analysis of dose response data (GraphPad Prism software). All compounds were tested in at least two independent experiments, each comprising eight replicates per concentration.

\section{Dosimetry}

The Research Reactor was used as a neutron source for in vitro cell irradiation. Neutron irradiation was carried out at the vertical access of the thermal column of the Research Reactor, consisting of a graphite stacking that moderates the fission neutrons. Cell irradiation is performed on top of the graphite using an experimental design similar to that described by A. Irles et al and N. G. Oliveira et al. The radiation field at the irradiation facility was calculated using a general-purpose Monte Carlo code for radiation transport simulation and a detailed model which included a validated model of the reactor core was described A. C. Fernandes et al. The calculated neutron energy distribution was further adjusted via the multiple-foil activation method and standard unfolding codes. The intensity of the neutron beam varies with the distance from the core, i.e., is constant (within $\pm 3 \%$ ) in the parallel direction and decreases with increasing distance with a larger relative contribution of thermal neutrons as more graphite is traversed. The conventional thermal neutron fluence rate $\left(\phi_{0}\right)$ at the highest intensity position is $>10^{7}$ neutrons $\mathrm{cm}^{-2} \mathrm{~s}^{-1}$; the ratio between the epithermal neutron fluence rate per unit lethargy $(\theta)$ and $\phi_{0}$ varies between $0.03 \%$ and $0.05 \%$ in the cell flask location. The contribution of epithermal neutrons to the dose received by the boron loaded cells is therefore negligible.

Regarding photon doses, low neutron sensitivity thermoluminescent dosimeters of $\mathrm{Al}_{2} \mathrm{O}_{3}: \mathrm{Mg}, \mathrm{Y}$ were used to evaluate the accuracy of the photon simulations and measure the photon dose itself. It was concluded that the major (>99\%) contribution to the photon dose is neutron interactions with the facility materials; therefore, a direct relation between the photon dose and the thermal neutron fluence can be derived. Details of the procedures was described Fernandes $e t$ al. The neutron fluence and photon dose received by the cells in the actual irradiation was monitored using pure gold foils underneath the cell flasks. The ratio of the foil response to the thermal and epithermal neutron fluence rates and to the photon dose rate was previously determined in a calibration run.

\section{In vitro cell neutron irradiation}

Prior to irradiation, the cells in culture flasks at a density of approximately $10^{6}$ cells per $5 \mathrm{~mL}$ medium were pre-incubated for $1 \mathrm{~h}$ with the compounds at a concentration of $200 \mu \mathrm{M}$ in medium. Thereafter the cells were irradiated at room temperature for $5 \mathrm{~h}$.

The maximum discrepancy between the measurements and this reported value is $17 \%$ due to the neutron fluence gradient within the irradiation facility. Exponentially growing cells were distributed in the following groups: (1) untreated cells without neutrons; (2) cells + neutrons; (3) cells with the compounds at 200 $\mu \mathrm{M}$ without neutrons; and (4) cells with the compounds at $200 \mu \mathrm{M}+$ neutrons. Cells that have not been treated with the boron compounds were used as controls. Following irradiation, the cells were placed in boron free medium under a humidified atmosphere containing $5 \% \mathrm{CO}_{2}$ at $37^{\circ} \mathrm{C}$. After $24 \mathrm{~h}$ the cellular viability was evaluated by the MTT assay. The absorbance of 
the resulting solutions was measured at 570 $\mathrm{nm}$ using a Varian DMS $80 \mathrm{UV}$-Vis spectrophotometer.

\section{Boron analysis by ICP-MS}

The total cellular boron content was analysed by Inductively Coupled Plasma Mass Spectrometer (ICP-MS). The glioblastoma cells (approx. $10^{6}$ cells $/ 5 \mathrm{~mL}$ medium) were exposed to the compounds at $200 \mu \mathrm{M}$ for $6 \mathrm{~h}$ at $37^{\circ} \mathrm{C}$, and then washed with ice-cold PBS and centrifuged to obtain a cellular pellet. The cytosol, membrane/particulate, cytoskeletal and nuclear fractions were extracted using a FractionPREPTM cell fractionation system (BioVision, USA) and performed according to the manufacturer's protocol. The boron content in the different fractions was measured after digestion of the samples in a closed pressurized microwave digestion unit (Mars5, CEM) with medium pressure HP500 vessels and then diluted in ultrapure water to obtain $2.0 \%(\mathrm{v} / \mathrm{v})$ nitric acid. The instrument was tuned using a multielement ICP-MS $71 \mathrm{C}$ standard solution (Inorganic Venture). Indium $\left({ }^{115} \mathrm{In}\right)$ at $10 \mathrm{mM}$ was used as the internal standard.

\section{Uptake by fluorescence microscopy}

Cellular uptake of compounds was visualized by performing time-lapse confocal microscopy imaging of live cells.

Cells were imaged using a Zeiss LSM 510 META inverted laser scanning confocal microscope (Carl Zeiss, Germany) fitted with a large incubator at $37^{\circ} \mathrm{C}$ (Pecon, Germany) using a PlanApochromat 63/1.4 oilimmersion objective. Ethidium bromide fluorescence was detected using the $514 \mathrm{~nm}$ laser line of an argon laser $(45 \mathrm{~mW}$ nominal output) and a 530-600 nm band-pass filter. Hoechst fluorescence was detected using a diode $405 \mathrm{~nm}$ laser (50 mW nominal output) and a 420-480 nm band-pass filter. The fluorescence of $4 \mathrm{a}$ was detected using the $420-480 \mathrm{~nm}$ bandpass filter. A transmission detector (PMT) was used to provide a transmission light image of the sample by detecting the scanning $488 \mathrm{~nm}$ laser. The pinhole aperture was adjusted in both channels to achieve the same optical slice thickness $(1 \mu \mathrm{m})$.

\section{Ultrastructural analysis}

After irradiation (cells \pm compounds + neutrons) the culture medium was replaced by a primary fixative $(5 \mathrm{~mL})$ consisting of glutaraldehyde (3\%) in sodium cacodylate buffer $(\mathrm{pH} 7.3,0.1 \mathrm{M})$. After primary fixation for $2 \mathrm{~h}$ at $4^{\circ} \mathrm{C}$, the glutaraldehyde was replaced by sodium cacodylate buffer. The cells were scraped, pelleted, and embedded in agar (2\%) for further processing. The samples were washed in cacodylate buffer and secondarily fixed for $3 \mathrm{~h}$ in osmium tetroxide (1\%) in sodium cacodylate buffer $(\mathrm{pH} 7.3,0.1 \mathrm{M})$. Then samples were washed with acetate buffer ( $\mathrm{pH} 5.0,0.1 \mathrm{M})$ and further fixed in uranyl acetate $(0.5 \%)$ in the same buffer for $1 \mathrm{~h}$. Dehydration was carried out with increasing concentrations of ethanol. After passage through propylene oxide, the samples were embedded in Epon-Araldite with the use of SPI-Pon as an Epon 812 substitute. Thin sections were made with glass or diamond knives and stained with aqueous uranyl acetate (2\%) and Reynold's lead citrate. The stained sections were assessment and photographed with a JEOL 100-SX electron microscope.

\section{DISCUSSION}

\section{Cytotoxicity}

In order to evaluate the cytotoxicity of 
compound and also to select a dose for irradiation, the glioma cells, a clinically relevant tumor cell line for BNCT.

A low cytotoxicity for a boronated agent is an important parameter in BNCT so that boron concentrations within tumors can be maximised. The cytotoxic activity of the boron compounds was determined using the MTT assay which evaluates the reduction of the tetrazolium salt by a mitochondrial dehydrogenase in metabolic active cells to insoluble formazan crystals was described by E. Vega-Avila et al. The cellular viability in the presence of the tested compounds was compared to that observed in controls (no additions) and the cellular viability (\%) was calculated. As an example of the corresponding inhibition curves (effect on cellular viability vs. compound concentration) compounds can be seen in Figure 2.

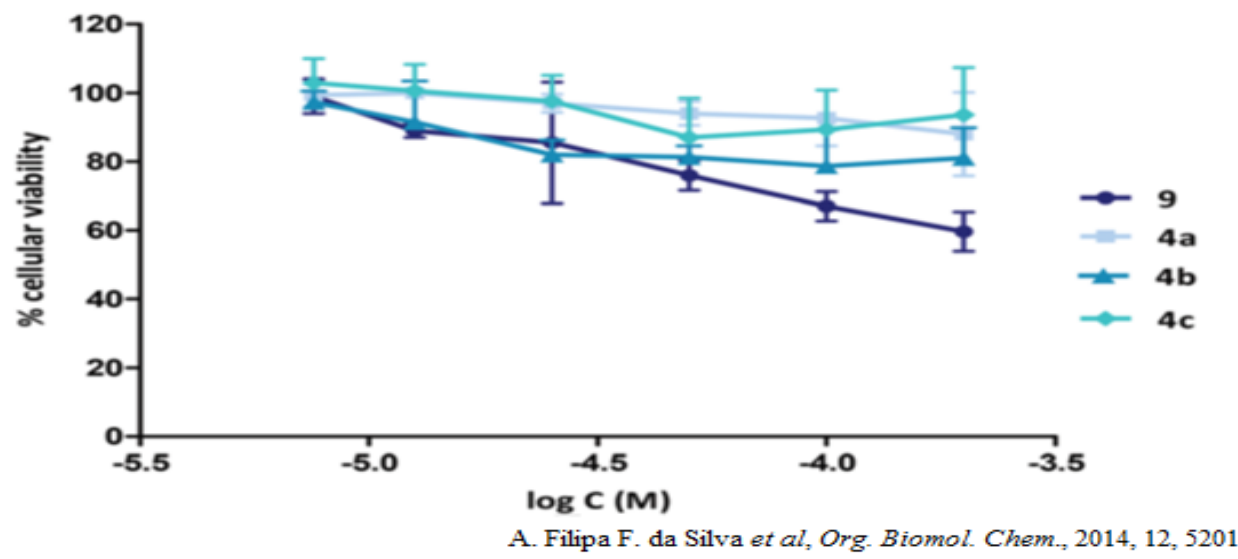

Figure. 2 Cellular viability (\%) of U87 cells after a $6 \mathrm{~h}$ treatment period with the boron compounds 9 and $4 \mathbf{a}-$ c. Results are expressed as mean $\pm \mathrm{SD}$ of 2 independent experiments with at least six replicates.

\section{In vitro $\mathrm{BNCT}$}

To assessment the potential of BNCT agents, their cytotoxic activities towards cells were tested after neutron irradiation for $5 \mathrm{~h}$ at room temperature. Compounds were added at an equimolar concentration of $200 \mu \mathrm{M}$. The cellular viability was determined by the MTT assay after $24 \mathrm{~h}$ incubation in compound free medium. The viability of cells after neutron irradiation in the presence or absence of the tested compounds was compared to that observed in controls (cells only). Neutron irradiation induced an increase in the cytotoxic effect. As an example the viability of cells can be seen in Figure. 3. 


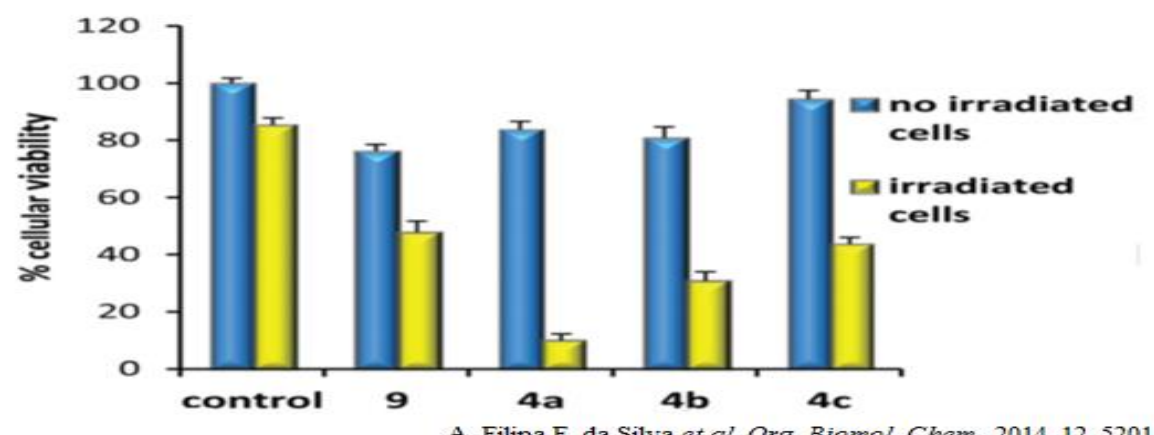

Figure. 3 Cellular viability (\%) of U87 cells after neutron irradiation. Cells with or without compounds were irradiated at room temperature for $5 \mathrm{~h}$ at a nominal thermal neutron fluence rate of $6.6 \times 10^{7}$ neutrons $\mathrm{cm}^{-2} \mathrm{~s}^{-1}$, at $1 \mathrm{MW}$. After irradiation cellular viability was evaluated by the MTT assay. Results as mean \pm SD of 2 independent experiments show a significant cytotoxic effect induced by neutron irradiation, in particular for compound $4 \mathbf{a}$.

\section{Cellular distribution by ICP-MS}

Comparative cellular distribution studies of compound with the cells were conducted in order to determine the boron content delivered by the compound. As an example the boron content was determined by inductively-coupled plasma mass spectroscopy (ICP-MS) in cytosol, membrane/particulate, nucleus and cytoskeletal fractions isolated from cells after $6 \mathrm{~h}$ exposure to the compounds at $200 \mu \mathrm{M}$ can be seen as an example in Figure. 4
This result indicates that compounds can target cellular components present mainly at the membrane or cytoskeleton, but without a cytotoxic effect, a factor that is critical in the design of new agents for BNCT. Moreover, the concentration of boron deposited into the cell is adequate for this therapeutic modality. We calculated an uptake of approx. $1.4 \times 1011 \mathrm{~B}$ atoms and consequently $2.8 \times 101010 \mathrm{~B}$ atoms per cell, an amount superior to the recommended concentration of 108-109 10B atoms according to E. L. Crossley et al.
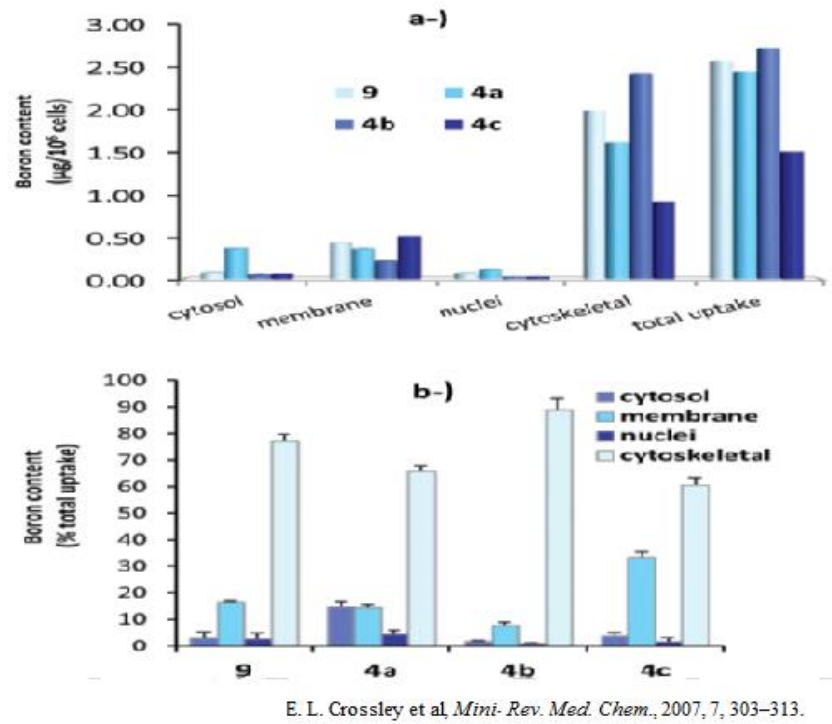

Figure. 4 The subcellular distribution (boron content) of the carboranylmethylacridones into the U87 cells. Cells were incubated with the compounds at $200 \mu \mathrm{M}$ for a $6 \mathrm{~h}$ challenge. The cytosol, membrane/ particulate, nuclear and cytoskeletal fractions were extracted and their bcron content was determined by ICP-MS. Results show the boron content expressed as: (a) $\mu \mathrm{g} / 10^{6}$ cells and (b) percentage of total uptake (mean $\pm \mathrm{SD}$ of 2 independent experiments). 


\section{Cytotoxicity}

The cellular trafficking of compounds was assessment by timelapse confocal fluorescence microscopy in live cells by taking advantage of their fluorescence properties. As an example depicted in Figure. 5, rapidly accumulates in the glioblastoma cells but not significantly in the nucleus.

A
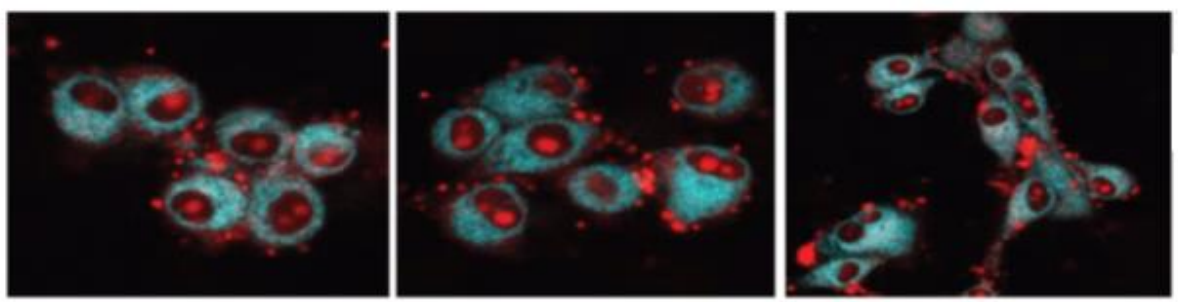

B
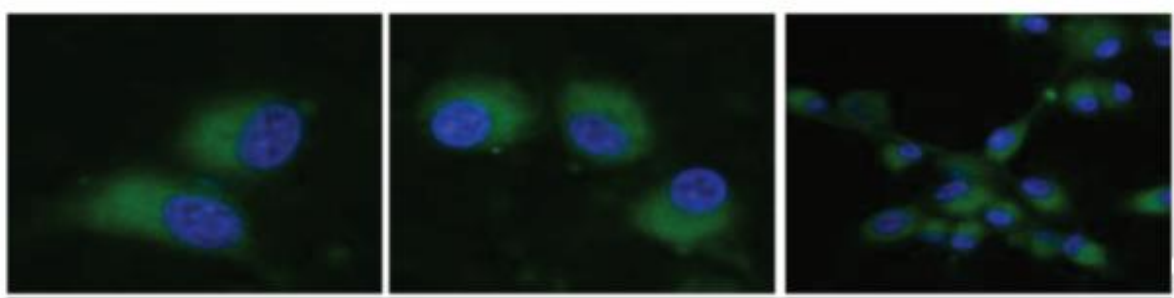

A. Filipa F. da Silva et al, Org. Biomol. Chem., 2014, 12, 5201

Figure. 5 Fluorescent live-cell imaging of the carboranylmethylbenzo[b]-acridones $\mathbf{4 a}(\mathrm{A})$ and $\mathbf{4 c}(\mathrm{B})$ in the U87 cells visualized by time-lapse confocal microscopy. The whole cell or cell nuclei were stained with DHE (4a) shown in red or Hoechst 33342 (4c) shown in blue. After incubation with the dyes for $10 \mathrm{~min}$, the cells were washed with PBS and the compounds were added at $200 \mu \mathrm{M}$. Images in blue (4a) or green (4c) channels were acquired after a 30 min time period.

\section{CONCLUSIONS}

Glioblastoma has long been the focus of BNCT research due to its radioresistance and infiltrative growth pattern. Clinical and experimental BNCT using BSH and BPA has shown potential but no proven therapeutic advantages. Research is therefore justified to further evaluate this experimental treatment modality. Recent literature reports discussed some of the more recent results and progress in BNCT, providing hope for this unique and exciting mode of clinical therapy. Two criteria must be fulfilled for clinical application of BNCT: an adequate source of high flux thermal neutrons along with a boron carrier that is able to concentrate in glioma cells and tissues. A high concentration of boron within tumor cells should be obtained in order to maximize the therapeutic effect.

The compound enter the cells and deposit an adequate amount of $\mathrm{B}$ atoms $(2.8 \times 101010 \mathrm{~B}$ atoms per cell) superior to the recommended concentration of 108-109 10B atoms. The compound also fulfilled the requirement of a low cytotoxicity. Therefore, although further studies need to be done, this results as an example suggest that compound carboranylmethylbenzo[b]acridin- $12(7 \mathrm{H})$-one may be considered as a lead compound for a new generation of BNCT agents although implications for therapy applications are at present obviously only exploratory.

\section{REFERENCES}

A. C. Fernandes, J. P. Santos, J. G. Marques, A. Kling, A. R. Ramos and N. P. Barradas 
(2010), Validation of the Monte Carlo model supporting core conversion of the Portuguese Research Reactor (RPI) for neutron fluence rate determinations, Ann. Nucl. Energy, 37, 1139-1145.

A. Crivello, C. Nervi, R. Gobetto, S. G. Crich, I. Szabo, A. Barge, A. Toppino, A. Deagostino, P. Venturello and S. Aime (2009), Towards improved boron neutron capture therapy agents: evaluation of in vitro cellular uptake of a glutamine-functionalized carborane, J. Biol. Inorg. Chem.,14, 883-890.

A. H. Soloway, R. F. Barth, R. A. Gahbauer, T. E. Blue and J. H. Goodman (1997), The rationale and requirements for the development of boron neutron capture therapy of brain tumors, J. Neurooncol.,33, 9-18.

A. Irles, I. C. Gonçalves, M. C. Lopes, A. C. Fernandes, A. G. Ramalho and J. Pertusa (2001), A biological study on the effects of high and low LET radiations following boron neutron capture reaction at the Portuguese Research Reactor, Phys. Med.,17, 17-19.

A. Omuro and L. M. DeAngelis (2013), Glioblastoma and other malignant gliomas: a clinical review, JAMA, 310, 1842-1850.

A. Paul, P. Sengupta, Y. Krishnan and S. Ladame (2008), Combining GQuadruplex Targeting Motifs on a Single Peptide Nucleic Acid Scaffold: A Hybrid (3+1) PNA-DNA Bimolecular Quadruplex, Chem. - Eur. J.,14, 86828689.

A. Wittig, R. L. Moss and W. A. Sauerwein (2014), Glioblastoma, brain metastases and soft tissue sarcoma of extremities: Candidate tumors for BNCT, Appl.

Radiat. Isot.,88, 46-49.

C. Caruso, M. Carcaterra and V. Donato (2013), Role of radiotherapy for high grade gliomas management, J. Neurosurg. Sci., 57, 163-169.
C. Fernandes, I. C. Gonçalves, J. Santos, J. Cardoso, L. Santos, A. F. Carvalho, J. G. Marques, A. Kling, A. J. G. Ramalho and M. Osvay (2006), Dosimetry at the Portuguese Research Reactor using thermoluminescent measurements and Monte Carlo simulations, Radiat. Prot. Dosimetry, 120, 349-353.

C. H. Hsieh, Y. F. Chen, F. D. Chen, J. J. Hwang, J. C. Chen, R. S. Liu, J. J. Kai, C. W. Chang and H. E. Wang (2005), Evaluation of pharmacokinetics of 4borono- $2-{ }^{18}$ F-fluoro-L- Phenylalanine for boron neutron capture therapy in a gliomabearing rat model with hyperosmolar blood-brain barrier disruption, J. Nucl. Med.,46, 1858-1865.

C. P. Tanase, A. M. Enciu, S. Mihai, A. I. Neagu, B. Calenic and M. L. Cruceru (2013), Anti-cancer Therapies in High Grade Gliomas, Curr. Proteomics, 10, 246260.

C. Viñas i Teixidor (2013), The uniqueness of boron as a novel challenging element for drugs in pharmacology, medicine and for smart biomaterials, Future Med. Chem.,5, 617-619.

D. R. Lu, S. C. Mehta and W. Chen (1997), Selective boron drug delivery to brain tumors for boron neutron capture therapy, Adv. Drug Delivery Rev., 26, 231-247.

E. L. Crossley, E. J. Ziolkowski, J. A. Coderre and L. M. Rendina (2007), Boronated DNA- binding compounds as potential agents for boron neutron capture therapy, Mini- Rev. Med. Chem., 7, 303-313.

E. Vega-Avila and M. K. Pugsley (2011), An Overview of Colorimetric Assay Methods Used to Assess Survival or Proliferation of Mammalian Cells, Proc. West. Pharmacol. Soc.,54, 10-14.

G. Cholewiński, K. Dzierzbicka and A. M. Kolodziejczyk (2011), Natural and synthetic acridines/acridones as antitumor agents: their biological activities and methods of synthesis, Pharmacol. Rep.,63, 305-336. 
I. B. Sivaev and V. V. Bregadze (2009), Polyhedral Boranes for Medical Applications: Current Status and Perspectives, Eur. J. Inorg. Chem.,14331450.

J. Bonjoch, M. G. Drew, A. González, F. Greco, S. Jawaid, H. M. Osborn, N. A. Williams and P. Yaqoob (2008), Synthesis and evaluation of novel boroncontaining complexes of potential use for the selective treatment of malignant melanoma, J. Med. Chem.,51, 66046608.

J. Kaur and P. Singh (2011), ATP selective acridone based fluorescent probes for monitoring of metabolic events, Chem. Commun.,47, 4472-4474.

J. Yoo and Y. Do (2009), Synthesis of stable platinum complexes containing carborane in a carrier group for potential BNCT agents, Dalton Trans.,4978-4986.

M. A. Pisarev, M. A. Dagrosa and G. J. Juvenal (2007), Boron neutron capture therapy in cancer: past, present and future, Arq. Bras. Endocrinol. Metabol.,51, 852-856.

M. Koba and T. Baczek (2011), Physicochemical interaction of antitumor acridinone derivatives with DNA in view of QSAR studies, Med. Chem. Res.,20, 1385-1393.

M. M. Mrugala (2013), Advances and challenges in the treatment of glioblastoma: a clinician's perspective, Discov. Med., 15, 221-230.

M. W. Easson, F. R. Fronczek, T. J. Jensen and M. G. H. Vicente (2008), Synthesis and in vitro properties of trimethylamine- and phosphonate substituted carboranylporphyrins for application in BNCT, Bioorg. Med. Chem.16, 3191-3208.

N. G. Oliveira, M. Castro, A. S. Rodrigues, I. C. Gonçalves, C. Martins, J. M. Toscano Rico and J. Rueff (2005), Effect of poly(ADP-ribosyl)ation inhibitors on the genotoxic effects of boron neutron capture reaction, Mutat. Res.,583, 36-48.

N. P. Barry and P. J. Sadler (2012), Dicarbacloso-dodecarboranecontaining halfsandwich complexes of ruthenium, osmium, rhodium and iridium: biological relevance and synthetic strategies, Chem. Soc. Rev.,41, 3264-3279.

P. Belmont and I. Dorange (2008), Acridine/acridone: a simple scaffold with a wide range of application in oncology, Expert Opin. Ther. Pat.,18, 1211-1224.

R. F. Barth (2009), Boron neutron capture therapy at the crossroads: challenges and opportunities, Appl. Radiat. Isot., 67, S3S6.

R. F. Barth, A. H. Soloway and R. M. Brugger (1996), Boron neutron capture therapy of brain tumors: past history, current status, and future potential, Cancer Invest.,14, 534-550.

R. F. Barth, J. A. Coderre, M. G. Vicente and T. E. Blue (2005), Boron neutron capture therapy of cancer: current status and future prospects, Clin. Cancer Res.,11, 39874002.

R. Gahbauer, N. Gupta, T. Blue, J. Goodman, R. Barth, J. Grecula, A. H. Soloway, W. Sauerwein and A. Wambersie (1998), Boron neutron capture therapy: principles and potential, Recent Results Cancer Res., 150, 183-209.

R. J. Harrison, A. P. Reszka, S. M. Haider, B. Romagnoli, J. Morrell, M. A. Read, S. M. Gowan, C. M. Incles, L. R. Kelland and S. Neidle (2004), Evaluation of by disubstituted acridone derivatives as telomerase inhibitors: the importance of Gquadruplex binding, Bioorg. Med. Chem. Lett.,14, 5845-5849.

R. L. Moss (2014), Critical review, with an optimistic outlook, on Boron Neutron Capture Therapy (BNCT), Appl. Radiat. Isot., 88, 2-11.

R. P. Evstigneeva, A. V. Zaitsev, V. N. Luzgina, V. A. Ol'shevskaya and A. A. Shtil (2003), Carboranylporphyrins for boron neutron capture therapy of cancer, 
Curr. Med. Chem.: Anti-Cancer Agents, 3, 383-392.

R. S. G. R. Seixas, A. M. S. Silva, D. C. G. A. Pinto and J. A. S. Cavaleiro (2008), A New Synthesis of Benzo[b]acridones, Synlett,3193-3197.

S. Altieri, S. Bortolussi, R. F. Barth, L. Roveda and A. Zonta (2009), Thirteenth International Congress on Neutron Capture Therapy, Appl. Radiat. Isot., 67, S1-S2.

S. Michel, T. Gaslonde and F. Tillequin (2004), Benzo[b]acronycine derivatives: a novel class of antitumor agents, Eur. J. Med. Chem.,39, 649-655.

S. Ronchi, D. Prosperi, C. Thimon, C. Morin and L. Panza (2005), Synthesis of mono- and bisglucuronylated carboranes, Tetrahedron: Asymmetry,16, 39-44.

T. Betzel, T. Heß, B. Waser, J. C. Reubi and F. Roesch (2008), Closo-Borane conjugated regulatory peptides retain high biological affinity: synthesis of closo-borane conjugated Tyr3-octreotate derivatives for BNCT, Bioconjugate Chem.,19, 1796-1802.

T. Kageji, Y. Mizobuchi, S. Nagahiro, Y. Nakagawan and H. Kumada (2011), Clinical results of boron neutron capture therapy (BNCT) for glioblastoma, Appl. Radiat. Isot.,69, 1823-1825.

T. Nguyen, G. L. Brownell, S. A. Holden, S. Kahl, M. Miura and B. A. Teicher (1993), Subcellular distribution of various boron compounds and implications for their efficacy in boron neutron capture therapy by Monte Carlo simulations, Radiat. Res.,133, 33-40.

T. Yamamoto, K. Nakai and A. Matsumura (2008), Boron neutron capture therapy for glioblastoma, Cancer Lett., 262, 143152. tissue sarcoma of extremities: Candidate tumors for BNCT, Appl. Radiat. Isot.,88, 46-49. Organic \& Biomolecular Chemistry Paper

W. Yang, R. F. Barth, G. Wu, T. Huo, W.
Tjarks, M. Ciesielski, R. A. Fenstermaker, B. D. Ross, C. J. Wikstrand, K. J. Riley and P. J. Binns (2009), Convection enhanced delivery of boronated EGF as a molecular targeting agent for neutron capture therapy of brain tumors, J. Neurooncol.,95, 355365. 